УДК 94(420)(=916)"17/19”(045)

\title{
Н.Ф. Шестакова
}

\section{КЕЛЬТСКОЕ ВОЗРОЖДЕНИЕ В ВЕЛИКОБРИТАНИИ (СЕРЕДИНА ХVІІІ - НАЧАЛО ХХ ВЕКА): ИДЕНТИЧНОСТЬ И ПАМЯТЬ ${ }^{1}$}

Статья посвящена Кельтскому возрождению - движению, связанному с подъёмом культуры народов Британских островов и с конструированием их региональных идентичностей на основе древнего прошлого. Автор проводит сравнительный анализ этого процесса на примере жителей Шотландии, Ирландии и Уэльса, выявляя особенности их самоидентификации в середине XVIII - начале XX вв. В статье предпринята попытка выявить причины начала Кельтского возрождения и установить его точные хронологические рамки. Автор приходит к выводу о том, что жители Шотландии и Уэльса стремились стать в рамках своего рода полноценными членами «британского содружества» и занять в нём достойное место. Воскрешение образов кельтского прошлого в памяти народов этих регионов было ориентировано на сохранение идентичности, в то время как в Ирландии - на борьбу за независимость, а в Англии — на прославление и защиту империализма.

Ключевые слова: кельты, Уэльс, Ирландия, Шотландия, кельтское возрождение, идентичность, историческая память.

\section{DOI: 10.35634/2412-9534-2019-29-4-583-592}

В 1890 г. в галерее «Гросвенор» в Лондоне была выставлена картина шотландских художников Джорджа Генри и Эдварда Аткинса Хорнела «Шествие друидов за омелой», которая стала настоящей сенсацией. Картина была вставлена в эффектную золотую рамку в виде переплетённых змей. На холсте была изображена дубовая роща, из которой выходит торжественная процессия «кельтских священников» и далее спускается по заснеженному холму [21]. Генри и Хорнел окутали создание картины мифической дымкой, отметив, что на её создание их вдохновили видения местного шамана, а изображение лиц друидов было основано на тщательном изучении обнаруженных археологами черепов жителей древней Британии. Действительно, для создания этой картины шотландские художники использовали археологические артефакты. Например, на шее у одного из друидов изображено ожерелье в виде золотого серпа, покрытого орнаментом бронзового века. Вдохновением для изображения этого ожерелья могли послужить пиктские камни, кельтские спирали на щите из Баттерси и чашевидные знаки на ландшафте Галлоуэя - области, расположенной на юго-западе Шотландии. Но, как выяснилось позже, для написания лиц четырёх центральных друидов художники всё же не использовали черепа друидов [19, p. 237]. Вместо них Генри и Хорнел прибегли к помощи фотографий, на которых были запечатлены лица коренных американцев. Эти фотографии получили широкое распространение благодаря представлению «Дикий Запад» Буффало Билла, которое было организовано в 1889 г. во время проведения Парижской выставки.

Подобно образам друидов, изображённым на картине Генри и Хорнела, и само Кельтское возрождение стало романтической реконструкцией прошлого древней Британии. Опираясь на открытия археологов и антиквариев, лингвистов и антропологов, британские деятели культуры, подражая давно ушедшей эпохе, попытались восстановить связь между прошлым и настоящим. Таким образом, Кельтское возрождение, датируемое, по нашему мнению, серединой XVIII - началом XX вв., является историческим периодом, характеризующимся расцветом литературы, культуры и искусства в таких регионах Британских островов, как Шотландия, Ирландия, Уэльс, Корнуолл и о. Мэн.

Начало Эпохи возрождения кельтской культуры, относящееся к середине XVIII в., стало ответом на набирающий силу процесс индустриализации, который вёл к забвению древних традиций и обычаев кельтских народов, а также к потере их связи с прошлым. Патриотически настроенные интеллектуалы и антикварии вынуждены были заняться «изобретением» новых традиций, церемоний, обрядов, а также составлением «книги памяти», содержащей пантеон героев и включавшей в себя набор национальных символов и эмблем. По своей сути «возрождение» было призвано оспорить

\footnotetext{
${ }^{1}$ Исследование выполнено при финансовой поддержке гранта Российского фонда фундаментальных исследований (проект № 18-39-00029 «Опыт конструирования региональной идентичности валлийцев на основе исторической памяти (конец XVIII- XX вв.)».
} 
идею формирования англоцентристской британской идентичности; оно явилось, с одной стороны, реакцией кельтских народов на унификацию британской культуры, а с другой — протестом против представления о кельтах как о ленивой, расточительной и выродившейся «расе». На характеризующийся расцветом национализма рубеж XIX-XX вв. пришлась кульминация «культурного ренессанса», способствовавшая оформлению такого художественного направления в искусстве, как модерн.

Изучению Кельтского возрождения в зарубежной исторической науке было уделено значительное внимание. Однако стоит отметить, что учёные сосредоточились в основном на исследовании этого «культурного ренессанса» на примере отдельно взятого региона. Историки Г. Каррутерс и А. Рэвис обращались к теме построения британской идентичности и к роли в этом процессе прошлого древней Британии и валлийской культуры в период Романтизма и Викторианской Эпохи [11]. Характеру и масштабам британской идентичности посвящена работа «Объединение нескольких идентичностей: Британские острова (1750-1850)» Лоуренса Бруклисса и Дэвида Иствуда [8]. Труд Т. М. Керли «Сэмюэль Джонсон, Оссиановская подделка и Кельтское возрождение в Великобритании и Северной Ирландии» оказался связанным не только с исследованием литературной мистификации Макферсона, который опубликовал свои стихи, выдавая их за поэзию древнего шотландского барда Оссиана, и взглядов Сэмюэля Джонсона на эту подделку, но и значительное внимание уделил развитию этнокультурных идентичностей британских народов в период Кельтского возрождения [14]. Валлийский исследователь Приз Морган в труде «Ренессанс XVIII в.» (1981) выдвинул гипотезу о том, что этнокультурная идентичность народа Уэльса, существующая с эпохи Средневековья, из-за распространения методизма и начала процесса индустриализации оказалась в XVIII в. под угрозой полного уничтожения и была искусственно реконструирована местными патриотами и интеллектуалами [32]. Наконец, стоит отметить труд «Модернизм и Кельтское возрождение» английского филолога Грегори Касла, в котором он изложил результаты исследования влияния антропологии на творчество писателей в Ирландии на рубеже XIX-XX вв. Автору удалось продемонстрировать, как представители модернизма использовали разработанные в антропологии текстовые формы и риторические модели для перевода и редактирования ирландского фольклора [12].

Кельтское возрождение сыграло важную роль в конструировании на основе памяти о кельтском прошлом национальной идентичности валлийцев, шотландцев и ирландцев. По нашему мнению, именно эта эпоха выявила основные «маркеры», которые в настоящее время определяют самобытность каждого из вышеперечисленных кельтских народов. В данном исследовании наше внимание будет сосредоточено на конструировании валлийской идентичности. Однако с целью избежать однобокости в суждениях и представить полную картину этого процесса необходимо провести сравнение и комплексный анализ моделирования национальной идентичности не только в Уэльсе, но также в Шотландии и Ирландии. Проведение подобного анализа конструирования идентичности народов Ирландии, Шотландии и Уэльса в период «Кельтского возрождения» позволит, во-первых, точно установить хронологические рамки этого периода, которые в зарубежной историографии довольно размыты; во-вторых, выделить общие черты построения на основе прошлого этнокультурной идентичности народов кельтских периферий в виде ответной реакции на формирование единой британской идентичности.

В ходе сравнительного анализа Кельтского возрождения в Ирландии, Шотландии и Уэльсе нам удалось выделить ряд общих черт, характерных для конструирования идентичностей народов, населявших Британские острова в середине XVIII - начале XX вв.

1. Поиск исторических корней и глубокий интерес к исследованию и развитию родных языков. Началу Кельтского возрождения предшествовало активное изучение британскими интеллектуалами древней истории. Поиск корней и открытие древнего бриттского прошлого находились в центре внимания антиквариев ещё в XVI в. В 1582 г. поэт, драматург и учёный Джордж Бьюкенен опубликовал труд «История Шотландии», в котором идентифицировал бриттов, пиктов и кельтов [9]. Опираясь на классические источники и топонимы, Бьюкенен пришёл к выводу, что только шотландцы и ирландцы произошли от кельтов, прародиной которых был регион, известный как «Галлия» (Лион, Франция), и жители которого путешествовали в Ирландию и Шотландию, минуя Гибралтарский пролив. Труд «Британия» Уильяма Кэмдена, опубликованный на латинском языке в 1586 г., ещё больше подорвал веру в подлинность «Истории бриттов» Гальфрида Монмутского (XII в.) [10]. Опираясь на «Записки о Галльской войне» Гая Юлия Цезаря, Кэмден утверждал, что слово «бритт» происходит не от имени легендарного сына Энея — «Брута», а от слова "brith" или "brit”, что означает 
Кельтское возрождение в Великобритании (середина XVIII - начало XX века)...

585

«окрашенный» [33, p. 17]. Кэмден основывал свои суждения на упоминании Цезарем некоего мужчины, тело которого было покрыто синей краской.

Публикация труда Кэмдена совпала с деятельностью английского художника Джона Уайта, впервые предпринявшего попытку визуализировать облик древних жителей Британии. Ему удалось выявить несколько сходных черт пиктов с древними бриттами. Художник создал несколько эскизов с изображением обнажённой пиктской женщины и мужчины-воина, тела которых были покрыты синей краской и украшены татуировками [41]. Пиктские воины были вооружены ятаганами и копьями; один из них держал в руке человеческую голову. Стоит отметить, что в XVI в. ятаганами вооружались турки, которых современники Уайта воспринимали как варваров. Сравнение пиктов с коренными американцами было предпринято художником с целью подчеркнуть «примитивное» происхождение бриттов, а также показать, что аборигены Британии в прошлом жили точно так же, как и коренное население Вирджинии [19, р. 239].

Попытки определить этническое происхождение населения «туманного Альбиона» продолжали предпринимать интеллектуалы XVII в. Французский филолог Самуил Бохарт в своём труде «Географическая сакра» (1646) высказал предположение, что первыми британцами были финикийцы [7, p. 70]. В 1676 г. Эйлетт Саммс, автор книги «Древности Британии», идентифицировал финикийцев с кельтскими друидами [38].

Впервые же идея о кельтах как коренных жителях Британских островов была изложена в труде «Кельтские языки» французского антиквария Поля-Ива Пезрона, опубликованном в 1703 г. и переведённом на английский язык в 1706 г. под названием «Народы древности» [36]. Принимая во внимание предположение Пезрона о том, что кельтский язык лёг в основу возникновения многих европейских языков, валлийский лингвист и антиквар Эдвард Ллуйд в труде «Археология Британии» (1707) утверждал, что кельтское происхождение имеют только народы, проживающие в Бретани, Уэльсе, Корнуолле, Ирландии и Шотландии [29]. Со временем применительно к этим регионам (с последующим дополнением о. Мэн) появится определение «кельтский», которое будет олицетворять расовую сплоченность и культурную самобытность народов этих территорий.

В первой половине XVIII в. британские интеллектуалы стали считать кельтов создателями древних памятников, состоящих из огромных каменных глыб. Одна из наиболее ярких фигур, исследовавших памятники древней Британии, - английский антикварий Уильям Стьюкли, известный среди своих последователей как «отец британских древностей». Этот учёный первым исследовал Стоунхендж, а в 1721 г. изобразил археографические артефакты, найденные вблизи каменного круга в Эйвбери, назвав это место «кельтским храмом». Вдохновлённый работами своего современника - ирландского философа Джона Толанда, Стьюкли вскоре был очарован образами друидов и даже предпринял попытку возродить некоторые из их древних церемоний [19, p. 239]. В 1740 г. он опубликовал труд «Стоунхендж: храм, возвращённый британским друидам» [43], а три года спустя — «Эйвбери: храм британских друидов» [42]. Способность к целительству и таинственные ритуалы захватили романтическое воображение британских интеллектуалов, которые предприняли многочисленные публикации, содержавшие изображения благородных кельтов.

Отметим, что особенностью XVIII в. стало появление трудов, посвящённых древней истории каждого отдельно взятого кельтского региона. Так, в Ирландии была написана «Диссертация по древней истории Ирландии» (1753) Чарльза О'Конора [34] и «Введение в изучение истории древней Ирландии» Сильвестра О’Хэллорана (1772) [35]; в Уэльсе - «Восстановление древней Моны» Г. Роулендса [37]; в Шотландии - «Критическое эссе о древних обитателях северной части Британии» (1729) Томаса Иннеса [24]; «Новая история Шотландии от раннего времени до отмены наследственной юрисдикции в Шотландии в 1748 г.» (1797) Роберта Херона [22].

Поиск исторических корней и исследование каменных мегалитов, осуществлявшиеся британскими антиквариями и деятелями культуры, способствовали в дальнейшем обращению кельтских народов к своему культурно-историческому наследию, которое в Ирландии, Шотландии и Уэльсе стало прочным фундаментом для культурного подъёма.

2. Подделывание исторических документов и образцов средневековой поэзии. Фальсификация исторических рукописей стала ещё одной тенденцией Кельтского возрождения, наиболее ярко проявившись на севере и западе Британии. Так, в Шотландии «появилась» поэзия Оссиана, созданная поэтом и мистификатором Дж. Макферсоном; а в Уэльсе - поэзия Ливарха Хена и Дэвида ап Гвилима, фальсифицированная бардом и антикварием Йоло Морганугом [4]. Деятельность этих интеллектуалов породила два ключевых вопроса, по которым велись многочисленные споры и дискуссии, способство- 
вавшие возникновению состязательности между Ирландией, Шотландией и Уэльсом за право считаться истинным лидером «кельтского мира» и преемником его культурно-исторического наследия.

Одним из катализаторов движения за возрождение культуры кельтских народов стала полемика, развернувшаяся вокруг вопроса о подлинности поэзии древнего шотландского барда Оссиана $[14$, p. 22]. Этот спор привёл к обсуждению более существенного вопроса, связанного с родиной гэлов. Дж. Макферсон, в середине XVIII в. опубликовавший образцы поэзии Оссиана, утверждал, что гэлы из Каледонии заселили «Зелёный остров», а не наоборот. Этой точке зрения активно противостояли великий лексикограф С. Джонсон, ирландский историк Чарльз О'Конор и английский писатель Фердинандо Уорнер, которые стремились доказать, что поэмы Оссиана были всего лишь фальшивкой, предоставляющей возможность шотландским просветителям заявить об исключительной самобытности народа древней Каледонии и претендовать на первенство в кельтском мире.

В отличие от Ирландии, в которой интерпретация прошлого всегда была в центре национального конфликта и борьбы за независимость, в Уэльсе она оказалась ориентированной на то, чтобы валлийцы заняли достойное место в рамках своего рода «союза британских народов». В период Валлийского возрождения в структуру исторической памяти Уэльса вошли образы древнего друидического прошлого, всё чаще фигурировали средневековые мотивы, такие, например, как путешествие принца Мэдока на запад, правление Грифида ап Кинана, гибель Лливелина Последнего и завоевание Уэльса Эдуардом I, «предательство длинных ножей», восстание Оуайна Глиндура и т. д. В этот период ирландцы сделали своим «золотым веком» раннее средневековье, часто обращаясь при этом к историям о друидах ради обоснования идеи о том, что именно «изумрудный остров» в древности был родиной друидизма и центром учёности Европы. Это появилось в противовес утверждениям валлийских интеллектуалов Генри Роулендса и Йоло Моргануга, считавших остров Англси главной святыней и местом сосредоточения «кельтских священнослужителей». Среди ирландских историков Сильвестр О'Хэллоран относил возникновение друидизма к милезианскому завоеванию $[35$, p. 28] и утверждал, что в дохристианский период именно Ирландия была «школой всей Европы». Основываясь на идеях примитивизма (вере в «доброго дикаря») и апеллируя к друидическому учению, ирландские, валлийские и шотландские интеллектуалы пытались доказать высокую степень цивилизованности кельтских народов и продемонстрировать, что саксы, пришедшие на остров позже, находились на неизмеримо более низкой стадии развития. Это стремление продемонстрировать цивилизованность своих предков послужило главным императивом обращения валлийцев к образам друидического прошлого.

3. Изобретение символов и новых традиций, которые создатели заведомо превращали в анахронизмы. К концу XVIII в. под влиянием процесса индустриализации этнокультурная идентичность кельтских народов стала приходить в упадок. Интеллектуалы и патриоты с целью поддержания самосознания искусственно «реконструировали» прошлое, изобретая при этом новые традиции, символы и формируя новые мифы. Как примеры можно отметить шотландский килт, придуманный в 1730 г. английским промышленником Т. Роулинсом, и восстановление в конце XIX в. [23, p. 21] в Ирландии средневековой традиции использования «кельтских крестов» как надгробий, которая (традиция) распространилась по всей Великобритании и перебралась через Атлантический океан в Америку. В Уэльсе в конце XVIII в. Йоло Морганугом была изобретена романтическая церемония Горседд, способствовавшая возрождению средневекового музыкального и поэтического фестиваля Айстедвод [13, p. 124]. Подобные церемонии проводились также в Корнуолле и Бретани. На Айстедводе в 1838 г. в Абергавени состоялся первый кельтский «Конгрес», а в 1858 г. в Лланголлене Джон Уильямс ап Ител организовал первый фестиваль национальной музыки, поэзии и танца Айстеддвод. Стремление сохранить древние обычаи и языки, а также народные промыслы, поэзию и музыку способствовало созданию разрозненных обществ и ассоциаций, таких, как Кельтское королевское общество, основанное в 1820 г. в Шотландии, и пан-кельтское общество, возникшее в 1888 г. в Дублине. Уэльс был не единственным краем, где провели пан-кельтский конгресс. Он состоялся также в Дублине в 1901 г., в Абергавенни в 1904 г. и в Эдинбурге - в 1907 г. В нём участвовали представители шести кельтских регионов: Шотландии, Уэльса, Ирландии, о. Мэн, Корнуолла и Бретани [19, p. 255].

4. Использование мифологических сюжетов в литературе и кельтского орнамента в искусстве. Несмотря на то, что поиск исторических корней продолжался на протяжении XVI-XVIII вв., Кельтское возрождение в литературе и изобразительном искусстве набирало обороты в течение первой половины XVIII в. и достигло апогея публикацией в 1814 г. романа «Уэверли» Вальтера Скотта, благодаря которому был создан романтичный образ Шотландии, по сей день бытующий в сознании британцев 
Кельтское возрождение в Великобритании (середина XVIII - начало XX века)...

587

[1]. Многие считают, что начало Эпохи Кельтского возрождения было положено публикацией в 1757 г. пиндарической оды «Бард» Томаса Грея [20]. Поэма повествует о том, как английский король Эдуард I вторгся в Уэльс и приказал убить бардов. Последний уцелевший бард, преследуемый королевскими войсками, прежде чем броситься со скалы в воды р. Конви, предсказывает гибель правителя Англии. В XVIII в. в Уэльсе было принято считать, что средневековые барды являются потомками древних друидов, а их поэзия служит единственным ключом к познанию героического прошлого древней Британии $[25$, p. 2]. Таким образом, приказ Эдуарда I об уничтожении валлийских бардов стал символизировать, с одной стороны, урон, который был нанесён англичанами культуре Уэльса; с другой - утрату связи валлийского народа с кельтским прошлым, служившим основой его этнической идентичности.

Поэма вдохновила на создание многочисленных визуальных интерпретаций её сюжетов, которые нашли воплощение в одноимённых картинах «Бард» Томаса Джонса [27] и Филиппа Якоба де Лютербурга (1774) [30]. На картине последнего был изображён бард в одежде друида с длинной белой бородой, стоящий на краю холма. Он сжимает в руках свою арфу и, прежде чем прыгнуть в воду, поворачивается, дабы извергнуть из себя проклятие вторгнувшемуся в Уэльс войску Эдуарда I. Гравюра «Бард» Филиппа Якоба Лютербурга была использована для фронтисписа к книге «Музыкальные и поэтические реликвии валлийских бардов» (1784) Эдварда Джонса [25]. Художник и поэт Уильям Блейк, создавший 116 иллюстраций к стихотворению Томаса Грея, в 1797-1798 гг. подготовил эскиз титульного листа очередного издания оды «Бард», на котором изобразил друида с длинной белой бородой, золотой арфой в руках и в развевающемся одеянии, украшенном звёздами [5].

В конце XVIII в. благодаря творческой и изобретательской деятельности антиквариев, таких, как Уильям Оуэн Пью и Йоло Моргануг, бард превратился в главный символ валлийского народа. Пью, иллюстрируя свою персональную копию «Героических элегий Лливарха Хена», создал фронтиспис, на котором был изображён валлийский бард. Он также помог гравёру Аврааму Раймбаху воплотить образ валлийского мифического героя Ху Гадарна, из которого Йоло Моргануг сделал прародителя валлийского народа. Авраам Раймбах изобразил Ху Гадарна причалившим к берегу в коракле* и вступающим на валлийскую землю.

Когда художники, в свою очередь, стали визуализировать образ Оссиана, они снова прибегли к уже существовавшему бардовскому стереотипу. Датский художник Николай Абрахам Абильгор написал картину «Слепой бард Оссиан, исполняющий лебединую песню» (1785), в которой предложил ставший уже «стандартным» образ древнего поэта в виде седовласого друида, держащего в руках арфу [3]. В Шотландии Александр Рансиман был первым, кто воплотил в жизнь сюжеты поэзии шотландского барда, сосредоточившись на подвигах Фингала. В 1774-1777 гг. сэр Джеймс Клерк поручил этому художнику расписать в доме Пеникук в Мидлтоне стены лестничного марша и большого салона, который в дальнейшем получит название «Оссиановский холл» [19, р. 241].

В начале ХІХ в. ряд археологических открытий способствовал распространению Кельтского возрождения и в Ирландии. Обнаруженные артефакты были сохранены для потомков благодаря кропотливой работе таких людей, как художник Джордж Петри и антиквар сэр Уильям Уайльд, которые входили в состав комитета Ирландской королевской академии. Петри удалось приобрести ценные рукописи и образцы металлических изделий, таких, как Конгский крест, в настоящее время хранящийся в Национальном музее Ирландии. Уильям Уальд, будучи выдающимся представителем Эпохи Кельтского возрождения, назвал своего сына (в будущем известного писателя) «Оскар Фингал» в честь двух героев поэм Оссиана. Он опубликовал трёхтомный каталог древностей, ныне хранящихся в Академии, среди которых были и металлические изделия, включавшие чашу из Ардага и брошь из Тары. Обнаруженная в 1850 г. возле Беттистауна брошь из Тары (VIII в.) открыла глаза викторианцам на красоту и утончённость работ раннехристианских мастеров и способствовала расцвету искусства изготовления изделий из металлов в Эпоху Кельтского возрождения.

Копии броши из Тары и других находок, относящихся к VIII в. (брошь Килмейнхема, брошь «Ягодное дерево»), были созданы ювелирной компанией «Г. и С. Уотерхаус» (G. \& S. Waterhouse) и приобретены Музеем мануфактур (ныне Музей Виктории и Альберта). Коммерческое дело этой компании было поддержано королевой, которая приобрела копию броши из Тары, положив, таким образом, начало моде на украшения в этническом стиле. В 1849 г. Виктория и принц Альберт посетили Тринити-колледж в Дублине, где были восхищены красотой Келлской книги и арфы Брайана Бору, а также изяществом древних золотых фибул с серебряными и бронзовыми брошками. Принц Альберт

\footnotetext{
* Традиционная валлийская лодка.
} 
втайне приобрёл две броши, одной из которых была булавка для шали, созданная ювелиром Эдмундом Джонсоном. Альберт подарил её на Рождество Виктории. В настоящее время эта брошь, известная как Кларендон, является копией броши IX в., найденной в Баллиспеллане. Поверхность оригинала покрыта серебряной зернью, в то время как королевская версия — гранатом. Любовь Виктории к этим кельтским украшениям была всем хорошо известна, и когда в 1853 г. королева посетила Дублинскую выставку, ей подарили т. н. брошь «Королева», которая являлась копией броши Кавана из озера Рамора (IX в.) [19, p. 247].

В XIX в. источниками вдохновения для мастеров и художников были труды, посвящённые изучению археологических артефактов. Во вступлении к иллюстрированному каталогу древних изделий «Грамматика орнамента» (1856) Оуэна Джонса были проанализированы истоки кельтского искусства, в т. ч. «кельтского орнамента» [26]. Исследование, основанное на археологических данных, также было проведено Джоном Кемблом и отражено в его книге «Изучение археологии северных народов» (1863), опубликованной после смерти автора Робертом Гордоном Лэтем и Августом Волластоном Фрэнксом [28]. Ключевая особенность этого труда - иллюстрации археологических находок, таких, как щит Баттерси. Почти 50 лет спустя этот артефакт будет использован шотландским художником Джоном Дунканом при написании картины «Всадники Сида», на которой он изобразил сидящих верхом на лошадях представителей сказочных племён богини Дану [16].

На рубеже XIX-XX вв. использование кельтского орнамента как декора на предметах ремесленного производства стало главным проявлением Кельтского возрождения в Шотландии, Ирландии и Уэльсе. Одним из таких ремёсел была резьба по дереву. Популяризация этого вида деятельности способствовала восстановлению народной традиции: изготовления скамеек с высокими спинками, украшенными кельтскими узлами или сценами из ирландской мифологии. Резьба по дереву была излюбленным занятием и у валлийских мастеров. Большое распространение в Уэльсе в этот период получила традиция изготовления из дерева «ложек любви». Молодые люди вырезали ложки, украшая их кельтским орнаментом и символами, несущими скрытый смысл, а после дарили их понравившимся девушкам [2].

В конце XIX - начале XX в. археологические открытия, а также ранее переведённые леди Шарлоттой Гест из Уэльса, Мари Анри д’Арбуа Жюбенвилем из Франции, В. Б. Йейтс и леди Грегори из Ирландии, Фионой Маклеод из Шотландии образцы кельтской поэзии и мифы, способствовали расцвету художественного творчества. Один из ярких художников этого периода - Джон Дункан, создавший ряд картин, в которых воплощены легендарные сюжеты. Среди наиболее известных его творений стоит отметить картину «Тристан и Изольда» (1912), на которой изображены корнуэльский рыцарь Тристан и ирландская принцесса Изольда, приготовившиеся выпить любовное зелье, чтобы умереть [17]. Наконец, стоит отметить, что в 1890-е гг. художественное «кельтское» творчество в Шотландии достигло своего расцвета в рамках т. н. «школы Глазго», представителями которой были Ч. Р. Макинтош, Джеймс Герберт Макнейр, Маргарет и Фрэнсис Макдональд.

5. Формирование пантеона национальных героев. Формированию национальных идентичностей кельтских народов способствовало также оформление кельтского пантеона героев, в рамках которого наиболее выделялись Теудорих Маур, Кухулин и Каратак. Теудорих Маур бы правителем Гвента и Морганнуга (Уэльс). В 610 г. он успешно защитил своё королевство от вторжения саксов, но был смертельно ранен. Скульптура «Смерть Теудориха Маура» Джона Эвана Томаса являет нам воина, умирающего на руках безутешной дочери Марселлы под звуки арфы и пение древнего барда [45]. Своего рода эквивалентом в ирландской визуальной культуре является бронзовая скульптура «Умирающий Кухулин» (1911) Оливера Шеппарда, которая изображает ирландского героя, смертельно раненого в бою и привязанного к камню Клохафармору (Clochafarmore Stone), как Христос к кресту [40]. На плече Кухулина сидит Морриган, кельтская богиня войны, ожидающая момента, когда его жизнь окончательно угаснет. Образ умирающего Кухулина стал олицетворять решимость ирландского народа во что бы то ни стало добиться независимости от Британской империи. В 1935 г. по просьбе политического лидера Ирландии Имона де Валера статуя была установлена в здании Главпочтамта в Дублине в память о Пасхальном восстании 1916 г. Стоит отметить, что Кухулин стал также символом культурного возрождения и был признан пан-кельтским героем в Шотландии. Джон Дункан не только написал картину «Пробуждение Кухулина», но и создал получивший широкую известность рисунок, находящийся в настоящее время в Национальной галерее Шотландии [15].

Герои железного века, такие, как Карадог или Каратак (обычно называемый «Карактак»), король триновантов, и Боудика, королева иценов, тоже оказались в центре внимания в Викторианскую 
Кельтское возрождение в Великобритании (середина XVIII - начало XX века)...

эпоху. Переосмысливая прошлое, деятели культуры сделали этих героев символами жертв империализма, считая, что они являют олицетворение храбрости и упорства британской нации, а также воплощение решимости защитить родину от вторжения чужеземцев (римлян). Каратак был сыном короля катувеллаунов Кунобелина. Он управлял большей частью южной Британии с 43-го по 47 год н. э. и возглавил местное сопротивление вторгнувшимся на остров римским войскам под руководством Авла Плавтия [6]. Согласно римскому историку Тациту, Каратак также возглавил племена силуров и ордовиков в борьбе против сил римского полководца Публия Октория Скапулы. В 50 г. н. э. он потерпел поражение и вынужден был бежать на север, где был схвачен и передан римлянам Картимандуей (Cartimandua), правительницей кельтского племени бригантов [31, p. 58]. В Риме его приговорили к смертной казни, но он смог убедить императора Клавдия пощадить его. В викторианский период Каратак стал олицетворением преданности родине и патриотизма. Примечательно, что в 1862 г. лошадь по кличке «Каратак» стала победительницей Эпсомского дерби, а в 1898 г. сэр Эдуард Элгар сочинил кантату для хора с оркестром под названием «Сaractacus», повествующую о бриттском вожде, защищавшем свой народ [18].

В XIX в. слово «Boudicca», означающее «победа», создавало в сознании британцев семантическую связь между королевой Викторией и кельтской правительницей. Одним из самых ранних изображений последней была гравюра «Боудикка, произносящая речь перед иценами» (1843) Генри Кортни Селуса, которую художник написал специально для участия в конкурсе, проводимом Вестминстером [39]. Английскиму скульптору Томасу Торникрофту, изготовившему конную статую королевы Виктории в полный рост для Великой выставки 1851 г., принц Альберт заказал изготовить бронзовый монумент, посвящённый Боудикке и её дочерям. На создание этого монумента скульптора вдохновили строки Тацита, а также стихотворение «Боудикка» (1854) А. Теннисона [44]. Однако бронзовая скульптура, располагающаяся сейчас на набережной Темзы, будет отлита только после смерти Виктории в 1902 г. [46].

Подводя итоги, отметим, что Валлийский Ренессанс, датируемый серединой XVIII - началом XX вв., - это органичная часть Кельтского возрождения (середина XVIII - начало XX вв.) - движения, связанного с поиском исторических корней, восстановлением связи с древним прошлым и возрождением кельтской культуры. Несмотря на то, что «культурный ренессанс» охватил всю территорию Британских островов, в т. ч. и часть континента, нельзя точно установить его хронологические рамки. Правильнее будет сказать, что Эпоха Кельтского возрождения - это совокупность «возрождений», происходивших в конкретном регионе в определённый интервал времени. Так, в Шотландии и Уэльсе подъём литературы и искусства происходил на протяжении первой половины XVIII в. В Уэльсе «культурный ренессанс» начался в середине XVIII в. публикацией оды «Бард» Томаса Грея и завершился в начале XIX в. после изобретения церемонии Горседда и оживления средневекового фестиваля Айстедвод. В Шотландии начало Кельтскому возрождению было положено в середине XVIII в. публикацией Макферсоном поэзии «Оссиана»; а его кульминация, связанная с творчеством писателя В. Скотта, пришлась на начало XIX в. В это же время произведённые археологические открытия способствовали развитию литературы и искусства в Ирландии. Здесь под воздействием роста национализма пик «культурного ренессанса» пришёлся на конец XIX - начало XX вв. - периода, характеризующегося расцветом модернизма в ирландской литературе и искусстве, а также проведением ряда мероприятий, направленных на сохранение гэльского языка и культуры.

В XVIII - начале XX вв. Уэльс и Шотландия пошли по пути политического нейтралитета, прославляя своё происхождение возрождением мифов, поэзии и искусства, а также конструируя свою идентичность, отличную от идентичности английских соседей. В Англии кельтское прошлое использовалось в пропагандистских целях, а именно: для прославления империализма, в то время как в Ирландии «ренессанс» приобрёл политический характер в связи с борьбой ирландского народа за независимость. В эпоху Кельтского возрождения (середина XVIII - начало XIX вв.) с помощью искусственно созданного «исторического каркаса» была закрыта временна́я брешь между минувшим прошлым и настоящим и сформирована основа для ныне существующих вариантов шотландской, ирландской и валлийской идентичностей.

Конечно, в данной статье рассмотрена лишь небольшая верхушка «айсберга», под названием Кельтское возрождение. Дальнейшее изучение темы может быть связано с более глубоким исследованием этого явления в сферах литературы и искусства народов Британских островов. С Кельтским возрождением связаны многочисленные дискуссии по проблемам национализма и конструирования идентичности, которые по сей день сохраняют свою актуальность и служат ответом на вопрос о том, почему этот период британской истории не перестаёт очаровывать? 


\section{СПИСОК ИСТОЧНИКОВ И ЛИТЕРАТУРЫ}

1. Скотт B. Собрание сочинений: Уэверли, или шестьдесят лет назад. М.: Мир книги, 2015. 523 с.

2. Суровегина М. Ложки любви // URL: http://www.celtica.ru/content/view/1453/340/

3. Abildgaard N. A. Ossian: The Old Blind Scottish Bard Singing his Swan Song to the Harp. The Athenaeum. URL: http://www.the-athenaeum.org/art/detail.php?ID=69397

4. Barddoniaeth Dafydd ab Gwillym. Iolo Morganwg. URL: http://www.iolomorganwg.wales.ac.uk/dylanwad.php

5. Blake $W$. The Bard. Yale center for British art. URL: http://interactive.britishart.yale.edu/art-in-focus-wales/167/thepoems-of-thomas-gray-design-53-the-bard

6. Blis P. B. A Brief History of the Celts. L., Robinson, 2003. URL: https://books.google.ru/books ?id=ERie BAAAQBAJ\&pg=PT163\&dq=Caractacus $+43+$ century+BC.\&hl=ru\&sa=X\&ved=0ahUKEwj597fr3ezfAhXJqIsKH Z11DWkQ6AEISzAF\#v=onepage\& $\mathrm{q}=$ Caractacus $\% 2043 \% 20$ century $\% 20 \mathrm{BC} . \& \mathrm{f}=$ false

7. Bocharti S. Geographia Sacra. Zunner, J. Davidis, 1681, vol. I. 360 p.

8. Brockliss L., Eastwood D. A. Union of Multiple Identities: The British Isles, C. 1750 - C. 1850. Manchester, Manchester University Press, 1997, 222 p.

9. Buchanan G., Aikman J. The history of Scotland. Glasgow, Blackie Fullarton; Edinburgh: Archibald Fullarton, 1827, vol. I-IV.

10. Camden $W$. Britannia. William Camden; ed. and introd. by R. Mayhew; reprint of the 1610 edition, transl. from the Latin by P. Holland. Bristol, Thoemmes, 2003, 860 p.

11. Carruthers G., Rawes A. English Romanticism and the Celtic World. Cambridge, Cambridge University Press, 2003, 265 p.

12. Castle G. Modernism and the Celtic revival. Cambridge, Cambridge University Press, 2001, $312 \mathrm{p}$.

13. Charnell-White C. A. Bardic Circles: National, Regional and Personal Identity in the Bardic Vision of Iolo Morganwg. Cardiff, University of Wales Press, 2007, 296 p.

14. Curley T. M. Samuel Johnson, the Ossian Fraud and the Celtic Revival in Great Britain and Ireland. Cambridge, Cambridge University Press, 2009, 348 p.

15. Duncan J. The Awakening of Cuchulain. Cuchulain of Muirthemne. URL: http://www.sacredtexts.com/neu/celt/cuch/index.htm

16. Duncan J. The Riders of the Sidhe. Celtic Buddhis. URL: https:/www.celticbuddhism.org/knights-of-the-tuatha-dedanaan/

17. Duncan J. Tristan and Isolde. Art UK. URL: https://artuk.org/discover/artworks/tristan-and-isolde-93241

18. Elgar E. Caractacus: A Cantata for Soprano, Tenor, Baritone, and Bass Soli, Chorus and Orchestra. Novello, 1898, $199 \mathrm{p}$.

19. Farley J., Hunter F. Celts art and identity. London, British Museum Press, 2015, 304 p.

20. Gray T. The Bard. A Pindaric Ode. Thomas Gray Archive. URL: http://www.thomasgray.org/cgibin/display.cgi?text=bapo

21. Henry G., Hornel E. A. The Druids: Bringing in the Mistletoe. Customer Experiences with soul. URL: https://cxwithsoul.files.wordpress.com/2018/01/img_0029.jpg

22. Heron R. A New General History of Scotland. Perth, Morison, 1794-1799, vol. I-VI.

23. Hobsbawm E., Ranger T. The Invention of Tradition. Cambridge, Cambridge University Press, 2000,320 p.

24. Innes T. A. Critical Essay on the Ancient inhabitants of Scotland. L., Innys, 1729, T I-II.

25. Jones E. Musical and poetical relicks welsh bards. L., 1794, 183 p.

26. Jones $O$. The Grammar of Ornament. L., Quaritch, 1868, 157 p.

27. Jones T. The Bard. Merran dub. URL: https://merranblog.files.wordpress.com/2014/10/thomas-jones_the_bard.jpg

28. Kemble J. Horae Ferales or Studies in the Archaelogy of the Northern Nation. L., Reeve, 1863, 251 p.

29. Lhuyd E. Archaeologia Britannica. L., Author, 1707, 476 p.

30. Loutherbourg P. J. The Bard. Art UK. URL: https://artuk.org/discover/artworks/the-bard-160193

31. Macdonald S., Holden P., Ardener S. Images of Women in Peace and War: Cross-cultural and Historical Perspectives. Wisconsin, The University of Wisconsin Press, 1987, $260 \mathrm{p}$.

32. Morgan P. The Eighteenth Century Renaissance. Llandybie, C. Davis, 1981, 174 p.

33. Morse M. A. How the Celts Came to Britain: Druids, Ancient Skulls and the Birth of Archaeology. Tempus, 2005, $222 \mathrm{p}$.

34. O'Conor Ch. Dissertations on the Antient History of Ireland. Dublin, Hoey, Reilly, 1753, $248 \mathrm{p}$

35. O'Halloran $S$. An introduction to the study of the history of the antiquities of Ireland: in which the assertions of Mr. Hume and other writers are occasionally considered. London, J. Murray, 1772, 384 p.

36. Pezron P. The Antiquity of the Nation of the Celts. L., Taylor and Francis, 1706, 312 p.

37. Rowlands H. Mona antiqua restaurata. L., J. Knox, 1766, 357 p.

38. Sammes A. Britannia Antiqua illustrata, Or the Antiquities of Ancient Britain. L., Roycroft, 1676, 582 p.

39. Selous H. C. Boudicca Harangued by the Iceni. The Victorian Web. URL: http://www.victorianweb.org/art/ illustration/selous/1.html 
40. Sheppard O. The Dying Cuchulain. Broadsheet. URL: http://cf.broadsheet.ie/wp-content/uploads/2014/12/cugpo.jpg

41. Smiles $S$. John White and British Antiquity: Savage Origins in the Context of Tudor Historiography. The British Museum. URL: https:/www.britishmuseum.org/pdf/4-Smiles-JW\%20and\%20British\%20Antiquity.pdf

42. Stukeley $W$. Abury, a temple of the British druids, with some others, described. L., Innys and Manby, 1743,102 p.

43. Stukeley W. Stonehenge: A Temple Restor'd to the British Druids. L., Innys and Manby, 1740. 66 p.

44. Tennyson A. Boadicea. PoemHunter.com. URL: https://www.poemhunter.com/poem/boadicea/

45. Thomas J. E. The Death of Tewdric. National Museum Wales. URL: https://museum.wales/art/online/?action= show item\&item $=2374$

46. Thornycroft T. Statue of Boudicca. Brewminate. URL: https://brewminate.com/boudicca-celtic-warrior-queen/

Поступила в редакцию 21.01.2019

Шестакова Надежда Фёдоровна, кандидат исторических наук, ассистент кафедры всеобщей истории ФГБОУ ВО «Уральский государственный педагогический университет» 620017, Россия, Свердловская область, г. Екатеринбург, просп. Космонавтов, 26 E-mail: shestakovanf@mail.ru

\section{N.F. Shestakova \\ THE CELTIC REVIVAL IN GREAT BRITAIN (MID-XVIII - EARLY XX CENTURIES): IDENTITY AND MEMORY}

DOI: $10.35634 / 2412-9534-2019-29-4-583-592$

The article is devoted to the Celtic revival, a movement related to the cultural development of the British Isles and the construction of their regional identities on the basis of the ancient past. The author carries out a comparative analysis of this process on the example of the inhabitants of Scotland, Ireland and Wales, revealing the features of their selfidentification in the middle of the XVIII - early XX centuries. The article attempts to identify the reasons for the beginning of the Celtic revival and establish its exact chronological framework. The author comes to the conclusion that the residents of Scotland and Wales sought to become full-fledged members of the "British Commonwealth" and take a worthy place in it. The revival of images of the Celtic past in the memory of the peoples of these regions was focused on the preservation of identity, while in Ireland - on the struggle for independence, and in England - on the glorification and protection of imperialism.

Keywords: Celts, Wales, Ireland, Scotland, Celtic revival, identity, historical memory.

\section{REFERENCES}

1. Skott $V$. Sobranie sochinenij: Uehverli, ili shest'desyat let nazad [Collection Works: Waverley Or 'tis Sixty Years Since...]. Moscow, Mir knigi Publ., 2015, 523 p. (In Russian).

2. Surovegina M. Lozhki lyubvi [Lovespoons]. URL: http://www.celtica.ru/content/view/1453/340/ (In Russian).

3. Abildgaard N. A. Ossian: The Old Blind Scottish Bard Singing his Swan Song to the Harp. The Athenaeum. URL: http://www.the-athenaeum.org/art/detail.php?ID=69397 (In English).

4. Barddoniaeth Dafydd ab Gwillym. Iolo Morganwg. URL: http://www.iolomorganwg.wales.ac.uk/dylanwad.php (In English).

5. Blake $W$. The Bard. Yale center for British art. URL: http://interactive.britishart.yale.edu/art-in-focus-wales/167/thepoems-of-thomas-gray-design-53-the-bard (In English).

6. Blis P. B. A Brief History of the Celts. L., Robinson, 2003. URL: https://books.google.ru/books? id=Erie BAAAQBAJ\&pg=PT163\&dq=Caractacus $+43+$ century + BC.\&hl=ru\&sa=X\&ved=0ahUKEwj597fr3ezfAhXJqIsKH Z11DWkQ6AEISzAF\#v=onepage\&q=Caractacus\%2043\%20century\%20BC.\&f=false (In English).

7. Bocharti S. Geographia Sacra. Zunner, J. Davidis, 1681, vol. I. 360 p. (In English).

8. Brockliss L., Eastwood D. A. Union of Multiple Identities: The British Isles, C. 1750 - C. 1850. Manchester, Manchester University Press, 1997, 222 p. (In English).

9. Buchanan G., Aikman J. The history of Scotland. Glasgow, Blackie Fullarton; Edinburgh: Archibald Fullarton, 1827, vol. I-IV. (In English).

10. Camden W. Britannia. William Camden; ed. and introd. by R. Mayhew; reprint of the 1610 edition, transl. from the Latin by P. Holland. Bristol, Thoemmes, 2003, 860 p. (In English).

11. Carruthers G., Rawes A. English Romanticism and the Celtic World. Cambridge, Cambridge University Press, 2003, 265 p. (In English).

12. Castle G. Modernism and the Celtic revival. Cambridge, Cambridge University Press, 2001, 312 p. (In English). 
13. Charnell-White C. A. Bardic Circles: National, Regional and Personal Identity in the Bardic Vision of Iolo Morganwg. Cardiff, University of Wales Press, 2007, 296 p. (In English).

14. Curley T. M. Samuel Johnson, the Ossian Fraud and the Celtic Revival in Great Britain and Ireland. Cambridge, Cambridge University Press, 2009, 348 p. (In English).

15.Duncan J. The Awakening of Cuchulain. Cuchulain of Muirthemne. URL: http://www.sacredtexts.com/neu/celt/cuch/index.htm (In English).

16. Duncan J. The Riders of the Sidhe. Celtic Buddhis. URL: https://www.celticbuddhism.org/knights-of-the-tuatha-dedanaan/ (In English).

17. Duncan J. Tristan and Isolde. Art UK. URL: https://artuk.org/discover/artworks/tristan-and-isolde-93241 (In English).

18. Elgar E. Caractacus: A Cantata for Soprano, Tenor, Baritone, and Bass Soli, Chorus and Orchestra. Novello, 1898, 199 p. (In English).

19. Farley J., Hunter F. Celts art and identity. London, British Museum Press, 2015, 304 p. (In English).

20. Gray T. The Bard. A Pindaric Ode. Thomas Gray Archive. URL: http://www.thomasgray.org/cgibin/display.cgi?text=bapo (In English).

21. Henry G., Hornel E. A. The Druids: Bringing in the Mistletoe. Customer Experiences with soul. URL: https://cxwithsoul.files.wordpress.com/2018/01/img 0029.jpg (In English).

22. Heron R. A New General History of Scotland. Perth, Morison, 1794-1799, vol. I-VI. (In English).

23. Hobsbawm E., Ranger T. The Invention of Tradition. Cambridge, Cambridge University Press, 2000,320 p. (In English).

24. Innes T. A. Critical Essay on the Ancient inhabitants of Scotland. L., Innys, 1729, T I-II. (In English).

25. Jones E. Musical and poetical relicks welsh bards. L., 1794, 183 p. (In English).

26. Jones $O$. The Grammar of Ornament. L., Quaritch, 1868, 157 p. (In English).

27. Jones T. The Bard. Merran dub. URL: https://merranblog.files.wordpress.com/2014/10/thomas-jones_the bard.jpg (In English)

28. Kemble J. Horae Ferales or Studies in the Archaelogy of the Northern Nation. L., Reeve, 1863, 251 p. (In English).

29. Lhuyd E. Archaeologia Britannica. L., Author, 1707, 476 p. (In English).

30. Loutherbourg P. J. The Bard. Art UK. URL: https://artuk.org/discover/artworks/the-bard-160193 (In English).

31. Macdonald S., Holden P., Ardener S. Images of Women in Peace and War: Cross-cultural and Historical Perspectives. Wisconsin, The University of Wisconsin Press, 1987, 260 p. (In English).

32. Morgan P. The Eighteenth Century Renaissance. Llandybie, C. Davis, 1981, 174 p. (In English).

33. Morse M. A. How the Celts Came to Britain: Druids, Ancient Skulls and the Birth of Archaeology. Tempus, 2005, 222 p. (In English).

34. O'Conor Ch. Dissertations on the Antient History of Ireland. Dublin, Hoey, Reilly, 1753, 248 p. (In English).

35. O'Halloran $S$. An introduction to the study of the history of the antiquities of Ireland: in which the assertions of Mr. Hume and other writers are occasionally considered. London, J. Murray, 1772, 384 p. (In English).

36. Pezron P. The Antiquity of the Nation of the Celts. L., Taylor and Francis, 1706, 312 p. (In English).

37. Rowlands H. Mona antiqua restaurata. L., J. Knox, 1766, 357 p. (In English).

38. Sammes A. Britannia Antiqua illustrata, Or the Antiquities of Ancient Britain. L., Roycroft, 1676, 582 p. (In English).

39. Selous H. C. Boudicca Harangued by the Iceni. The Victorian Web. URL: http://www.victorianweb.org/art/illustration/ selous/1.html (In English).

40. Sheppard O. The Dying Cuchulain. Broadsheet. URL: http://cf.broadsheet.ie/wp-content/uploads/2014/12/cugpo.jpg (In English).

41. Smiles S. John White and British Antiquity: Savage Origins in the Context of Tudor Historiography. The British Museum. URL: https://www.britishmuseum.org/pdf/4-Smiles-JW\%20and\%20British\%20Antiquity.pdf (In English).

42. Stukeley $W$. Abury, a temple of the British druids, with some others, described. L., Innys and Manby, 1743,102 p. (In English).

43. Stukeley $W$. Stonehenge: A Temple Restor'd to the British Druids. L., Innys and Manby, 1740. 66 p. (In English).

44. Tennyson A. Boadicea. PoemHunter.com. URL: https://www.poemhunter.com/poem/boadicea/ (In English).

45. Thomas J. E. The Death of Tewdric. National Museum Wales. URL: https://museum.wales/art/online/?action= show_item\&item=2374 (In English).

46. Thornycroft T. Statue of Boudicca. Brewminate. URL: https://brewminate.com/boudicca-celtic-warrior-queen/ (In English).

Shestakova N.F., Candidate of History, Assistant of the Department of General History Ural State Pedagogical University

Kosmonavtov Avenue, 26, Yekaterinburg, Russia, 620017

E-mail: shestakovanf@mail.ru 